\title{
Farmers Local Knowledge on Niche Selection, Management Strategies and Uses of Cordia africana Tree in Agroforestry Practices of Sidama Zone, Southern Ethiopia
}

\author{
Latamo Lameso ${ }^{1,}$, Wondmagegn Bekele ${ }^{2}$ \\ ${ }^{1}$ Kebri Dehar University College of Dry Land Agriculture Department of Natural Resource Management, Kebri Dehar, Ethiopia \\ ${ }^{2}$ Oromia Agricultural Research Institute, Sinana Agricultural Research Center of Agroforestry Research Team, Bale-Robe, Ethiopia
}

Email address:

latamo58@gmail.com (L. Lameso)

${ }^{*}$ Corresponding author

To cite this article:

Latamo Lameso, Wondmagegn Bekele. Farmers Local Knowledge on Niche Selection, Management Strategies and Uses of Cordia africana Tree in Agroforestry Practices of Sidama Zone, Southern Ethiopia. American Journal of Agriculture and Forestry.

Vol. 8, No. 6, 2020, pp. 258-264. doi: 10.11648/j.ajaf.20200806.14

Received: November 2, 2020; Accepted: November 17, 2020; Published: November 27, 2020

\begin{abstract}
In Ethiopia Cordia africana is one of the indigenous multipurpose tree species which is being endangered and suffering a lot from overexploitation. Agroforestry is taken as potential ecosystem for counteracting indigenous multipurpose trees species extinction through providing complementary habitat for such species. In Sidama zone of south Ethiopia, farmers deliberately integrate and manage $C$. africana tree by using their own indigenous knowledge for both its productive and protective functions. However, comprehensive study has not been undertaken to assess and document the local knowledge associated with $C$. africana tree. Thus, study was designed to assess local knowledge of farmers on niche selection, management practices and uses of $C$. africana tree in agroforestry practices of Sidama zone. To do so household survey, key informants' interview and focus group discussions were undertaken to generate the necessary data. A total of 126 sample respondents were randomly selected based on wealth category. In addition to this, about 72 sample households were considered for tree inventory purpose. The inventory was done in the niches of Coffee-Enset tree based, Coffee tree based and Enset-tree based homegarden agroforestry practice. Data were analyzed by using Statistical Package for Social Science (SPSS). Results obtained from the study show that, mean number of stems of tree is found to be significantly higher $(\mathrm{p}<0.05)$ in Ensettree based niche of homegarden agroforestry followed by Coffee-tree based niche. The finding also shows that mean basal area of tree in Enset-tree based niche was significantly $(p<0.05)$ higher of the remaining niches of agroforestry practices over both the midland and lowland agroecological zones. The commonly management practices employed for $C$. africana by the local farmers were branch pruning (80.6\% and $73.2 \%)$, coppicing $(32.2 \%$ and $42.8 \%)$ and pollarding $(33.8 \%$ and $19.6 \%)$ in midland and lowland agroecology, respectively. Farmers also have profound knowledge on uses of $C$. africana tree. From the reported uses; timber production, soil improvement, household utensils, shade and cash generation are the major ones as these could be also vary over age, size and parts of the species to be used. Finally, the study has suggested that, for a conclusive recommendation the effect of $C$. africana tree on coffee-Enset yield and yield component needs to be further investigated.
\end{abstract}

Keywords: Coffee-Enset-tree Based, Coffee-tree based, DBH, Enset-tree Based, Homegarden

\section{Background and Justification}

Rural people have a wealth of local knowledge and have included trees in agroforestry systems as one component in areas where they lived for a very long period of time [4]. Local knowledge is emerging as a dynamic resource based upon contemporary observation and experimentation rather than just a legacy from the past. This local knowledge helps farmers to deliberately grow and manage trees in agricultural landscapes [14]. It is common for farmers to manage natural regenerating multi-purpose trees within agricultural fields by protecting seedlings and young trees, mostly native species that have germinated from soil seedbanks. The integration of trees on farms are characteristic of a large part of the 
Ethiopian agricultural landscape for long time. While tree species management intensity and distribution varying with agroecological conditions principally defined by rainfall, altitude and soil type [13].

From this native multi-purpose tree species Cordia africana (Lam.) is an indigenous tree species which is extensively adopted and managed by farmers as a dominant feature of agricultural landscapes in the sub-humid zone of Ethiopia [21]. In Ethiopia, it grows well in the dry, moist and wet midland agroecological zone [5]. Farmers in southern Ethiopia integrate this tree within the homegardens and manage with their own local knowledge [16]. It is the dominant, widely used and wellknown species by the local farmers of Sidama zone, mostly in midland and lowland agroecology.

Cordia africana now becomes one of economic tree species, managed by farmers in their farmland as agroforestry tree. It was mainly aimed at improving the uptake of conservation agriculture through provision of timber, fuel wood, construction materials, agricultural implements, biomass, nutrients, fencing and for enhancement productive and service roles [18]. This has been promoting local people's interest in conservation and maintenance of such important and threatened species. In order to improve such productive and service roles of indigenous trees on farmland, farmers are aware of different tree management activities for optimizing tree crop interaction [3]. From these important tree management practices; pruning, pollarding of the upper parts, coppicing, thinning and lopping of side branches are major management practices mostly in agroforestry land use systems of southern Ethiopia [16].

Farmers in southern Ethiopia plant and retain Cordia africana for maintaining soil fertility in Enset-coffee based agroforestry [22]. It is one of the known top woody plant species for quality timber extraction in Ethiopia [17]. Sidama and Gedeo are notable places in southern Ethiopia by providing high quality furniture and household materials. The income generated from the sale of these products and the lumber itself, is one of the mechanisms for improving the livelihood of many rural poor farmers. It is also used by farmers as source of income and risk aversion during drought [16]. It is also used to produce different farm equipment's; plough, yoke, axe and digger [6].

The current distribution, habitats and the populations of $C$. africana (Lam.) are severely affected by deforestation, fragmentation and selective logging. Overharvesting due increased demand of people with high population growth is threatening the regeneration and sustainability of this tree species in Ethiopia. Due to this reason it is now proclaimed as one of the most threatened tree species [15]. Managing $C$. africana in agroforestry farming systems with farmer's local knowledge is one of the best options for maintaining sustainability of this tree species. In Ethiopia, some researchers have made studies on the different aspects of this tree, but there is no comprehensive study undertaken to address farmers' indigenous knowledge associated with this tree species. This may aggravate the extinction of $C$. africana further. For this reason, this study is initiated to identify farmers' local knowledge on the selection of proper niches, management activities and uses of Cordia Africana tree.

\section{Materials and Method}

\subsection{General Description of the Study Area}

This study was conducted in Sidama zone southern Ethiopia. Sidama zone is found at the coordinate of $38^{\circ} 27^{\prime} 43^{\prime \prime} \mathrm{E}$ and 39 31'78' E longitude and 5 45'33" $\mathrm{N}$ and $6^{\circ} 45^{\prime} 71^{\prime \prime} \mathrm{N}$ latitude with total area of $10,000 \mathrm{~km}^{2}$. It lays between Hawassa town in the north and Dilla town in the south, spread out in a cone-shaped area in the middle of southern Ethiopia (figure 1). It has three agroecological zones namely; highland (Dega) (16\%) ranging from an elevation of $2500 \mathrm{~m}$ to 3500 masl, midland (Woinadega) (54\%) from $1500 \mathrm{~m}$ to $2500 \mathrm{~m}$ asl and lowland (Qola) (30\%) $500 \mathrm{~m}$ to 1500 masl. The soil type in the study area dominantly classified as Nitosols and Eutric nitosols [20].

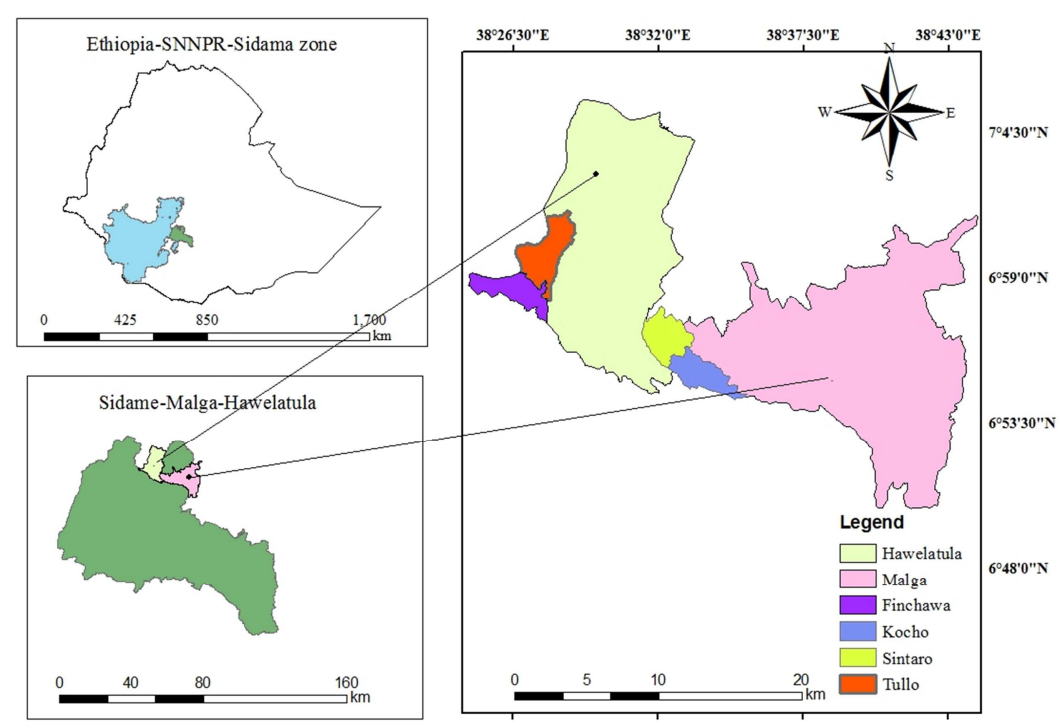

Figure 1. Map of study area. 


\subsection{Site Selection}

In the study, two districts Malga from midland agroecology and Hawelatula from lowland agroecology were selected purposively as result of $C$. africana is not grown in the highland agroecology $[5,12]$. Thereafter, two kebeles per districts are considered for the collection of study data.

\subsection{Data Collection}

Data were collected through household interview, focus group discussions and tree inventory. In doing so questionnaires, checklists and personal field observations were used to extract and compile the necessary information.

\subsubsection{Respondents Selection}

The selection of respondents was undertaken based on the wealth classes of households as the management of tree in agricultural landscape strongly influenced by socio-economic condition or wealth status of households [9]. In this respect, the households were stratified into three main wealth categories namely; wealthy, medium and poor [10]. Indeed, about $65^{`}$ respondents from midland and 61 from lowland, making a total of 126 sample size of respondent is used for this study.

\subsubsection{Niche Identification and Tree Inventory}

Following focus group discussion and personal field observations baseline information was generated for understanding of the existing homegarden agroforestry niche types. Based on this, the three traditional homegarden agroforestry niches (Coffee-Enset-tree based and Coffee-Tree based and Enset-tree based) were identified [1, 7].

Thereafter, inventory was employed for determining the current distribution and occurrence of $C$. africana over the identified each niche types. For this purpose, about 72 sample households were used by considering 3 households from each wealth category. Thereafter, plot size of $20 \mathrm{mx} 20 \mathrm{~m}$ were laid 'out (one plot per practice) for the identified niches of traditional homegarden agroforestry practices as used by [2]. Based on this, the number of total stems per plot, diameter at breast height $(\mathrm{DBH})$ at $1.3 \mathrm{~m}$ from the ground and total height were measured and recorded. Calipers and hypsometers were used to measure $\mathrm{DBH}$ and tree total height, respectively.

\subsection{Data Analyses}

Difference on the density or number of tree and basal area of study sites were examined by using one-way ANOVA with SPSS software. Tukey's test was used to test significance difference among any two means to identify variation at $5 \%$ level of error tolerance. Basal area is cross sectional area of tree stems at DBH. Generally, it is a measure of degree of a tree as an expression of space it occupies and calculated by $\mathrm{BA}=\frac{\pi \mathrm{d}^{2}}{4}$ mathematical equation. Where $\mathrm{BA}=$ Basal area in $\mathrm{m}^{2}, \mathrm{~d}=$ diameter at breast height $(\mathrm{m})$ and $\pi=3.14$. Data on different sources of seedlings, tree management practices and uses of $C$. africana tree were analyzed with multiple response tests by using SPSS software and presented in table form with frequency and percentage. In addition, the $\mathrm{DBH}$ class distribution of $C$. africana is presented by using bar-graph.

\section{Results and Discussion}

\subsection{Farmers' Local Knowledge for the Selection of Niche of Cordia Africana}

Result obtained from the study shows the mean number of stems varied among the three niches. Over both agroecology, significantly $(p<0.05)$ higher number of stems is reported for Enset-tree based niche of than coffee-tree based and coffeeEnset-tree based niche types. The explained reason for the higher number of $C$. african tree in Enset-tree based niche is three-fold. Firstly, the species is deliberately integrated and managed by farmers to make its growth performance faster and obtain better timber quality. As they suggested, when $C$. africana is planted in Enset-tree based niche its stem become very tall with a large size of diameter and this enabled farmers to increase timber quality of this species.

Table 1. Mean number of stems (per plot and per ha) under the three niches of traditional agroforestry practice

\begin{tabular}{llll}
\hline Agroecology & Niche & Number of stem/plots & Number of stems/ha \\
\hline & & Mean SD & Mean SD \\
\multirow{3}{*}{ Midland } & CETB & $1.52^{\mathrm{bc}} \pm 1.60$ & $40.92^{\mathrm{bc}} \pm 31.30$ \\
& CTB & $2.18^{\mathrm{b}} \pm 1.74$ & $51.22^{\mathrm{b}} \pm 43.62$ \\
& ETB & $2.61^{\mathrm{a}} \pm 1.54$ & $65.30^{\mathrm{a}} \pm 38.40$ \\
Lowland & CETB & $0.90^{\mathrm{bc}} \pm 1.21$ & $22.22^{\mathrm{bc}} \pm 30.34$ \\
& CTB & $1.50^{\mathrm{b}} \pm 1.80$ & $35.60^{\mathrm{b}} \pm 44.90$ \\
\hline
\end{tabular}

Note: -Different superscript letters in the same column indicates significant difference. $\mathrm{CETB}=\mathrm{Coffee}$-Enset-tree based, $\mathrm{CTB}=\mathrm{Coffee}$-tree based and $\mathrm{ETB}=$ Enset-tree based

Secondly, in addition to C. africana farmers integrate other shade providing and fruit tree species in coffee-Enset-tree based and coffee-tree based niche types. This reduces space provided for $C$. africana tree and resulted in lower mean number of $C$. africana tree stems. Thirdly, farmers prefer to plant and retain $C$. africana tree species in Enset-tree based niche type for keeping of its straightness and maintaining the quality of wood products to be obtained from the species. As they mentioned, in Enset-tree based niche of agroforestry practice, Enset enables to keep the straightness of $C$. africana 
tree thereby protecting from wind fall.

\subsection{Basal Area}

Statistically $(\mathrm{p}<0.005)$ the higher mean value of basal area reported for Enset-tree based niche type for both agroecological zones (table 2). This may attribute for the observed higher diameter class groups of trees in this niche type of than the remaining two niches (figure 2).

With respect to agroecology, the higher basal area was obtained from midland agroecology as many numbers of trees with higher DBH class recorded from this agroecology. The variation could be due to the better suitability of midland agroecology for C. africana against of lowland eco-zone [5]. Overall C. africana population structure attains inverted " $\mathrm{J}$ " curve graphical diameter class tree groups inferring as the size of diameter increase the number of trees decreases consistently (figure 2).

Table 2. Mean basal area per plot and per ha under the three niches of agroforestry practices

\begin{tabular}{llll}
\hline Agroecology & Niche & Basal area/plot $\left(\mathbf{m}^{\mathbf{2}}\right)$ & Basal area $/ \mathbf{h a}\left(\mathbf{m}^{\mathbf{2}}\right)$ \\
\hline \multirow{4}{*}{ Midland } & & Mean SD & Mean SD \\
& CETB & $0.27^{\mathrm{bc}} \pm 0.35$ & $2.22^{\mathrm{bc}} \pm 2.90$ \\
& CTB & $0.30^{\mathrm{ab}} \pm 0.27$ & $2.50^{\mathrm{ab}} \pm 2.21$ \\
& ETB & $0.50^{\mathrm{a}} \pm 0.60$ & $4.05^{\mathrm{a}} \pm 4.90$ \\
Lowland & CETB & $0.14^{\mathrm{b}} \pm 0.10$ & $1.20^{\mathrm{b}} \pm 0.85$ \\
& CTB & $0.12^{\mathrm{bc}} \pm 0.10$ & $1.00^{\mathrm{bc}} \pm 0.82$ \\
& ETB & $0.18^{\mathrm{a}} \pm 0.09$ & $1.50^{\mathrm{a}} \pm 0.76$ \\
\hline
\end{tabular}

Note: Different superscript letters in the same column indicates significant difference

$\mathrm{CETB}=$ Coffee-Enset-tree based, $\mathrm{CTB}=$ Coffee-tree based and $\mathrm{ETB}=$ Ensettree based

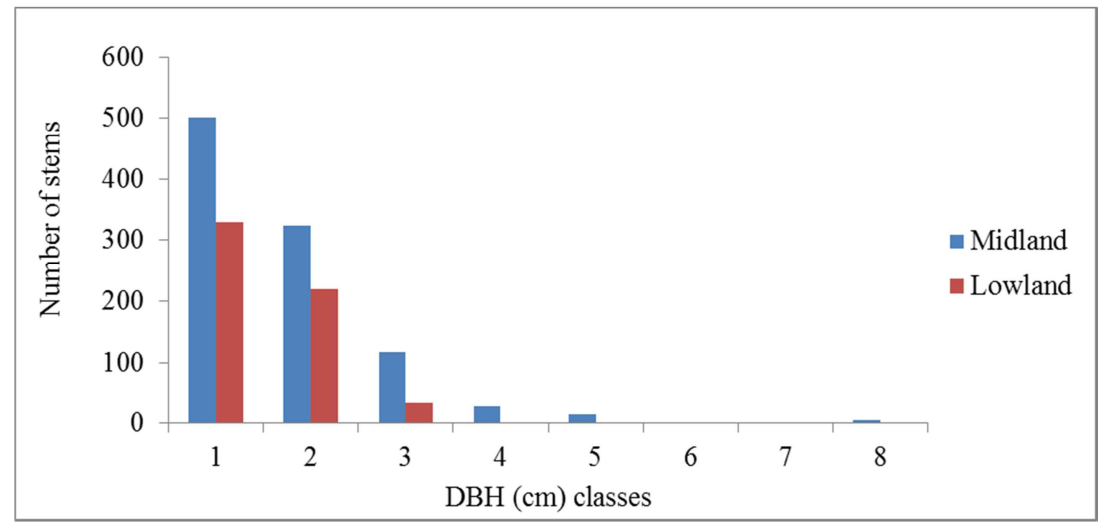

NB: $1=5-15.9,2=16-30.9,3=31-45.9,4=46-60.9,5=61-75.9,6=76-90.9,7=91-105.9$ and $8=\geq 106$.

Figure 2. Diameter class distribution of C. africana tree over the two agroecological zones.

\subsection{Management Practices of Cordia Africana}

The result has suggested that farmers have developed profound local knowledge for the management of $C$. africana tree under their agroforestry land use system. In this respect, pruning and lopping are the commonly management practices reported by farmers whereas thinning is the rarely practiced management (table 3). Depending up on farmer's objective these management practices are more/less implemented for different reasons (table 4). For instance, pruning is undertaken mainly for reducing heavy shade from Coffee and Enset, and collecting wood products to be used for dead fence and fuel. Lopping is practiced for keeping wood and timber quality thereby enabling to remove side branches of $C$ africana. It also used for making tree to grow taller without casting too much shade over Coffee and Enset.

Pollarding is also another management practice reported for the management of $C$. africana on farmers' field. It is implemented for reducing excessive shading from coffee and Enset along with facilitating air circulation for the underneath crops. Additionally, farmers also pollard C. africana when they need construction poles and timber in believing that pollarded C. african tree provides more durable, long lasting and termite resistant wood product.

Table 3. Major C. africana tree management practices in two agroecological zones.

\begin{tabular}{|c|c|c|c|c|c|}
\hline \multirow{3}{*}{ No } & \multirow{3}{*}{ Management practices } & \multicolumn{4}{|c|}{ Respondent in percent $(\mathrm{N}=118)$} \\
\hline & & \multicolumn{2}{|c|}{ Midland $(n=62)$} & \multicolumn{2}{|c|}{ Lowland $(n=56)$} \\
\hline & & Frequency & $\%$ & Frequency & $\%$ \\
\hline 1 & Pruning & 50 & 80.6 & 41 & 73.2 \\
\hline 2 & Pollarding & 21 & 33.8 & 11 & 19.6 \\
\hline 3 & Coppicing & 20 & 32.2 & 24 & 42.8 \\
\hline 4 & Lopping & 38 & 61.3 & 39 & 69.6 \\
\hline 5 & Thinning & 10 & 16.1 & 3 & 5.4 \\
\hline
\end{tabular}

Another management practice which is perceived as harvesting and direct use of $C$. africana is coppicing.
Farmers responded that coppicing is practiced to harvest timber and construction wood products either for own 
consumption and/or income generation via sale. They also stated that coppicing enables to initiate multiple stem growth from single tree stump and reduce the need to replant seedlings after harvesting (table 5). This was in line with study made by [11] who reported that coppicing avoids the need to replant trees after harvesting.

However, coppicing is becoming a threat for the sustainability of mother plants of $C$. africana in the study area. This is because currently mother plants of $C$. africana have been directly sold for local timber processing machineries. As the machineries are business oriented, they don't coppice the mother plant at the recommended stump height, even they remove with the stump.
Thinning is also the additional management practice reported by farmers. As they stated thinning is practiced to reduce competition by removing selected trees which are too slender for the desired size or economic value. From the total respondents interviewed, only $16.1 \%$ and $5.4 \%$ respondents use this management practice in midland and lowland agroecology respectively (table 4). The reason for rarely practicing of thinning is that farmers start to manage $C$. africana tree seedlings as early as regenerating naturally under their mother plant. Similar finding reported by $[8,18]$ show that to reduce density of tree in farmland, farmers remove less economic and undesired tree due to their size.

Table 4. Major reasons for the management practices of C. africana tree.

\begin{tabular}{|c|c|c|c|c|c|c|c|}
\hline \multirow{2}{*}{ No } & \multirow{2}{*}{$\begin{array}{l}\text { Reasons for each } \\
\text { management }\end{array}$} & \multirow{2}{*}{ Agroecology } & \multicolumn{5}{|c|}{ Frequency of respondents } \\
\hline & & & Pruning & Pollarding & Coppicing & Lopping & Thinning \\
\hline \multirow{2}{*}{1} & \multirow{2}{*}{ RS } & Midland & 49 & 13 & - & 38 & 7 \\
\hline & & Lowland & 38 & 6 & - & 32 & 2 \\
\hline \multirow{2}{*}{2} & \multirow{2}{*}{ FW } & Midland & 16 & 10 & 9 & 20 & 5 \\
\hline & & Lowland & 22 & 8 & 12 & 33 & 1 \\
\hline \multirow{2}{*}{3} & \multirow{2}{*}{$\mathrm{DF}$} & Midland & 26 & 8 & - & 15 & 4 \\
\hline & & Lowland & 19 & 4 & 7 & 18 & 2 \\
\hline \multirow{2}{*}{4} & \multirow{2}{*}{ FD } & Midland & 5 & - & - & 3 & - \\
\hline & & Lowland & 18 & - & - & 6 & - \\
\hline \multirow{2}{*}{5} & \multirow{2}{*}{ ML } & Midland & 8 & - & - & 9 & - \\
\hline & & Lowland & 10 & 2 & - & 10 & - \\
\hline \multirow{2}{*}{6} & \multirow{2}{*}{$\mathrm{RC}$} & Midland & - & 6 & 7 & 17 & 8 \\
\hline & & Lowland & 7 & 5 & 14 & 21 & 1 \\
\hline \multirow{2}{*}{7} & \multirow{2}{*}{$\mathrm{CS}$} & Midland & 14 & 9 & 21 & - & 7 \\
\hline & & Lowland & 20 & 3 & 18 & - & 2 \\
\hline \multirow{2}{*}{8} & \multirow{2}{*}{ DDL } & Midland & - & 15 & - & - & - \\
\hline & & Lowland & - & 9 & - & - & - \\
\hline \multirow{2}{*}{9} & \multirow{2}{*}{ WTQ } & Midland & - & 12 & - & 40 & - \\
\hline & & Lowland & - & 7 & - & 42 & - \\
\hline \multirow{2}{*}{10} & \multirow{2}{*}{ IG } & Midland & - & 5 & 20 & - & 5 \\
\hline & & Lowland & 6 & 8 & 22 & - & 1 \\
\hline \multirow{2}{*}{11} & \multirow{2}{*}{ TB } & Midland & - & - & 23 & - & - \\
\hline & & Lowland & - & - & 22 & - & - \\
\hline \multirow{2}{*}{12} & \multirow{2}{*}{ RSD } & Midland & - & - & - & - & 8 \\
\hline & & Lowland & - & - & - & - & 2 \\
\hline \multirow{2}{*}{13} & \multirow{2}{*}{ MT } & Midland & - & - & 19 & - & - \\
\hline & & Lowland & & - & 22 & - & - \\
\hline
\end{tabular}

Note:-RSH=reducing heavy shade effect, $\mathrm{FW}=$ using for fuelwood, $\mathrm{DF}=\mathrm{using}$ for dead fence, $\mathrm{FD}=\mathrm{using}$ for fodder, $\mathrm{CS}=\mathrm{using}$ for construction, $\mathrm{TB}=\mathrm{using}$ for timber, $\mathrm{ML}=$ using for mulch, $\mathrm{DDL}=$ to make timber and other wood products durable and long lasting, WTQ=for keeping wood and timber quality, $\mathrm{IG}=$ for sale income generation, $\mathrm{RC}=$ to reducing competition for nutrients, $\mathrm{RSD}=$ for removing slender, diseased and dead tree, $\mathrm{MT}=\mathrm{encouraging}$ multiple stem growth from single stump.

\subsection{Farmers' Knowledge on Uses of Cordia Africana Tree}

In the study about fourteen uses of $C$. africana tree species is reported by farmers (table 5). Timber production, soil improvement, household utensils, shade provision and cash generation are the major reported uses of $C$. africana. Farmers state the integration of $C$. africana tree with coffee and Enset improves soil fertility via reducing soil erosion and being good source of mulch material. Local handcraft and handsaw men from the study area revealed that $C$. africana tree widely used for household utensil material production. Notably door, window, chair, bed, beehives, mortar, pestles, cultural food materials and farm tools (plough, yoke) are the frequently mentioned household utensils obtained from this tree species. The report is consistent to study made by [6] who found that $C$. africana is one of the dominant tree species used for the production of different modern and cultural household utensils in Jima zone of western Oromia, Ethiopia. 
Table 5. Reported uses and benefits of C. africana tree in the study area.

\begin{tabular}{|c|c|c|c|c|c|}
\hline \multirow{3}{*}{ No } & \multirow{3}{*}{ Use category } & \multicolumn{4}{|c|}{ Respondents in\% (N=126) } \\
\hline & & \multicolumn{2}{|c|}{ Midland $(n=65)$} & \multicolumn{2}{|c|}{ Lowland $(n=61)$} \\
\hline & & Frequency & $\%$ & Frequency & $\%$ \\
\hline 1 & Timber & 58 & 89.2 & 41 & 67.2 \\
\hline 2 & Cash generation & 49 & 75.4 & 48 & 78.7 \\
\hline 3 & Fuelwood & 32 & 49.2 & 33 & 54.1 \\
\hline 4 & Food & 16 & 24.6 & 9 & 14.8 \\
\hline 5 & Medicine purpose & 10 & 15.4 & 11 & 18 \\
\hline 6 & Fodder & 15 & 23.1 & 20 & 32.8 \\
\hline 7 & Soil improvement & 57 & 87.7 & 51 & 83.6 \\
\hline 8 & Shade & 49 & 75.4 & 50 & 81.5 \\
\hline 9 & Bee forage & 10 & 15.8 & 6 & 10.1 \\
\hline 10 & Construction wood & 41 & 63.2 & 21 & 34.1 \\
\hline 11 & Cultural values & 8 & 12.3 & 9 & 14.8 \\
\hline 12 & Environmental benefits & 17 & 26.2 & 22 & 36.1 \\
\hline 13 & Household utensils & 55 & 84.6 & 45 & 73.8 \\
\hline 14 & Farm tools & 10 & 15.4 & 40 & 65.6 \\
\hline
\end{tabular}

Further, $C$. africana is reported as cash generating commodity by the local farmers. Respondent's, 74.5\% from midland and $78.7 \%$ lowland state that, it is highly suitable income generator commodity particularly during annual crop failures due to moisture stress. Hence, $C$. african tree management under farmers farming field considered as an alternative way of money deposited for their sudden expenditure. They also noticed $C$. africana tree used for provision of shade for the underneath annual and perennial crops. As they explained coffee with shade tree gives better coffee bean yield and cup quality of than coffee without shade.
However, the use of C. africana tree is determined by age, size and part (table 6). Results depicted in the table reveal stem and root parts of the tree could be used for making household utensils. In this respect; roots are more preferred for making mortars and some cultural food serving materials. This is because materials made from old $C$. africana root provide long lasting service with a better quality. Unlikely if the DBH class of tree $>25 \mathrm{~cm}$, farmer uses for timber production. Against, if $\mathrm{DBH}$ is $<25 \mathrm{~cm}$ they consider for traditional house construction, income generation and sometimes for fuelwood purpose (table 6).

Table 6. Major parts of C. africana tree and uses in relation to tree age and size.

\begin{tabular}{|c|c|c|c|c|c|}
\hline No & Plant parts & Tree age and size & Midland $n=65$ & Lowland $n=61$ & Uses \\
\hline \multirow[t]{2}{*}{1} & Stem & $>25 \mathrm{~cm} \mathrm{DBH}$ & 30 & 45 & $\begin{array}{l}\text { Timber, construction wood, cash generation, Household utensils, } \\
\text { cultural values, environmental benefits, fuel wood }\end{array}$ \\
\hline & & $8-25 \mathrm{~cm} \mathrm{DBH}$ & 25 & 20 & $\begin{array}{l}\text { Construction wood, dead fence, farm wools, fuelwood, cash } \\
\text { generation dead fence, environmental benefits }\end{array}$ \\
\hline 2 & Bark & $8-40 \mathrm{~cm} \mathrm{DBH}$ & 18 & 15 & Medicine, household utensils and fuelwood, \\
\hline 3 & Root & $>40 \mathrm{~cm}$ diameter & 20 & 18 & Household utensils, construction wood, fuelwood, farm tools \\
\hline & & Any size & 10 & 20 & Fuel wood, farm tools \\
\hline 4 & Leaf & At any size & 50 & 55 & $\begin{array}{l}\text { Soil improvement, medicine, fodder, shading, mulch, } \\
\text { environmental roles }\end{array}$ \\
\hline 5 & Fruit & Above 5 years old & 35 & 20 & Food, Juice \\
\hline 6 & Flower & Above 5 years old & 28 & 10 & Bee forage, soil fertility improvement, \\
\hline 7 & Branches & At any size & 40 & 35 & Fuelwood, construction wood, dead fence, \\
\hline
\end{tabular}

DBH (Diameter at Breast Height).

Farmers also have knowledge on medicinal uses of $C$. africana tree parts suggesting internal parts of bark chewed for tooth ache and swallowed for abdominal pain. Ripen fruits could be also eaten during morning time for gastric as succulent leaves used for wound remedy. This is in line with study made by [19] different parts of C. africana tree used as medicine for diseases such as wound, tooth ache, stomach ache, eye infection, abdominal pain and evil eye. The food and fodder value of $C$. africana is also reported by farmers. As to them ripen fruits could be used for making juices for human consumption whereas succulent leaves and flowers considered as fodder for livestock's and bee forage's during dry season.

\section{Summery and Conclusion}

In Ethiopia Cordia africana is one of the indigenous multipurpose tree species which is being endangered and suffering a lot from overexploitation for long period of time. Due to this, it is proclaimed as one of the most threatened tree species. Agroforestry systems serve as in situ conservation areas for many species that farmers value and therefore wish to conserve. Farmers in southern Ethiopia integrate this tree within the homegardens and manage with their local knowledge. Study was designed to assess local knowledge of farmers for niche selection, management 
practices and uses of $C$. africana tree in homegarden agroforestry practices of Sidama zone, Southern Ethiopia. To collect the necessary data; household survey, key informants' interview and focus group discussions were undertaken. In addition, tree inventory was employed in the niche of CoffeeEnset tree based, Enset-tree based and Coffee-tree based homegarden agroforestry practices.

The results of the study revealed that, mean number of stems of tree were significantly higher $(p<0.05)$ in Enset- tree based niche type followed by Coffee-tree based niche over both agroecological zones. Likely, the mean basal area is found to be higher in Enset-tree based niche. The study also found that branch pruning, coppicing and pollarding were most commonly used management practices for $C$. africana. Further, the study adds knowledge on uses of $C$. africana tree. In this respect timber production, soil improvement and household utensils, shade and cash generation are reported majorly. The food and fodder value of $C$. africana is also reported by farmers. However, these uses were found to be determined by age, size and parts of the species to be used. To sum up, for a conclusive recommendation study on the effect of $C$. africana tree on Coffee-Enset yield and yield component needs to be further investigated.

\section{References}

[1] Abebe, T., Wiersum, K. F., Bongers, F. \&Sterck, F. 2006. Diversity and dynamics in homegardens of southern Ethiopia. In: B. M. Kumar \& P. K. R. Nair (Eds.). Tropical homegardens: a time-tested example of sustainable agroforestry, p. 123-142.

[2] Abreha, A. and Gebrekidan, W., 2014. Woody Plant Inventory and Diversity in Traditional Agroforestry of Selected Peasant Association of South Gonder Zone, North West Ethiopia. Journal of Environment and Earth Science, 4 (15), pp. 8-16.

[3] Agidie, A., Ayele, B., Wassie, A., Hadgu, K. M., Aynekulu, E. and Mowo, J., 2013. Agroforestry Practices and Farmers' Perception in Koga Watershed, Upper Blue Nile Basin, Ethiopia. Agriculture and Forestry 59 (3), pp. 75-89.

[4] Anglaaere, L. C. N., Cobbina, J., Sinclair, F. L. and McDonald, M. A., 2011. The effect of land use system on tree diversity, farmer preference and species composition of Cocoa based agro ecosystem in Ghana. Agroforestry system, 81 (3), pp. 249-265.

[5] Azene, B., 2007. Useful Trees and Shrubs of Ethiopia: Identification, Propagation and Management in 17 Agroecological Zones. Nairobi: RELMA in ICRAF Project, p. 552.

[6] Balcha, A., 2013. Plants used in material culture in Oromo community, Jimma, Southwest Oromia, Ethiopia. African Journal of Plant Science, 7 (7), pp. 285-299.

[7] Beyene, T. M., Gerrie, W. J., Ken, E. and Giller, K. D., 2018. Home garden system dynamics in Southern Ethiopia. Agroforest System, 92, pp. 1579-1595.

[8] Bijalwan, A. and Dobriyal, M. J., 2016. Geometry, Distribution and Regeneration Pattern of Trees in Agroforestry Systems along Altitude and Aspects in the Upper Yamuna Region of Uttarakhand Himalaya, India. Applied Ecology and
Environmental Sciences, 4 (1), pp. 15-25.

[9] Bucagu, C., Vanlauwe, B., Van Wijk, M. T. and Giller, K. E., 2013. Assessing Farmers' Interest in Agroforestry in Two Contrasting Agro-Ecological Zones of Rwanda. Agroforestry systems, 87 (1), pp. 141-158.

[10] Crowley, E. L., 1997. Rapid data collection using wealth ranking and other techniques. International Centre for Research in Agroforestry (ICRAF), Nairobi, Kenya, p. 16.

[11] Desalegn, M. and Zebene, A., 2016. Assessment of Farmers' Management Activities on Scattered Trees on Crop Fields at Gemechis District, West Hararge Zone, Oromia, Ethiopia. International Journal of Agriculture, 1 (1), pp. 1-15.

[12] Friis, I. B., 1992. Forests and Forest Trees of Northeast Tropical Africa: Their Natural Habitats and Distribution Patterns in Ethiopia, Djibouti and Somalia. Her majestry's stationary office. Kew Bulletin Additional Series XV, p. 396.

[13] Gelaw, A. M., Singh, B. R. and Lal, R., 2014. Soil Organic Carbon and Total Nitrogen Stocks under Different Land Uses in a Semi-Arid Watershed in Tigray, Northern Ethiopia. Agriculture, Ecosystems and Environment, 188, pp. 256-263.

[14] Isaac, M. E., Dawoe, E. and Sieciechowicz, K., 2009. Assessing Local Knowledge Use in Agroforestry Management with Cognitive Maps. Environmental Management, 43 (6), pp. 1321-1329.

[15] Kebu, B. and Fassil. K., 2006. Ethnobotanical study of wild edible plants in Derashe and Kucha Districts, South Ethiopia. Journal of Ethnobiology and Ethnomedicine, 2 (1), p. 53.

[16] Mesele, N., 2007. Trees Management and Livelihoods in Gedeo's Agro forests, Ethiopia; A B Academic Publishers, Helsinki University; Great Britain. Forests, Trees and Livelihoods, 17 (2), pp. 157-168.

[17] Mulugeta, D., Assefa, F., Nemomissa, S. and Granhall, U., 2011. Socio-economic Benefits of Shade Trees in Coffee Production Systems in Bonga and Yayuhurumu Districts, Southwestern Ethiopia: Farmers' Perceptions. Ethiopian Journal of Education and Sciences, 7 (1), pp. 39-55.

[18] Mutua, J., Muriuki, J., Gachie, P., Bourne, M. and Capis, J., 2014. Conservation Agriculture with Trees: Principles and Practice. A Simplified Guide for Extension Staff and Farmers. World Agroforestry Center, Nairobi. Technical Manual No. 21. pp. 42-44.

[19] Reta, R., 2013. Diversity and Conservation Status of Some Economically Valued Indigenous Medicinal Plants in Hawassa College of Teacher Education Campus, Southern Ethiopia. International Journal of Advanced Research, 1 (3), pp. 308328.

[20] Sidama Development Corporation, Planning and Statistics (SDCPS). 2000. Sidama Development Corporation, Planning and Statistics bulletin

[21] Yadessa, A., Itanna, F. And Olsson, M., 2009. Scattered Trees as Modifiers of Agricultural Landscapes: The Role of Waddeessa (Cordia africana Lam.) Trees in Bako Area, Oromia, Ethiopia. African Journal of Ecology, 47 (1), pp. 7883.

[22] Zebene, A. and Agren, 2007. Farmers' Local Knowledge and Topsoil Properties of Agroforestry Practices in Sidama, southern Ethiopia. Agroforestry Systems, 71 (1), pp. 35-48. 